\title{
THE IMPACT OF CZECH COMMUTERS ON THE GERMAN LABOUR MARKET
}

\author{
Michael Moritz
}

\begin{abstract}
:
In the process of European integration, regions close to a border are especially affected by labour market liberalisation. Using data from the IAB employment subsample (IABS) and the employment register $(\mathrm{BeH})$ for the period before and after the opening of the border between Germany and the Czech Republic (1980-2001) I shed light on the development of wages. Both German employees and Czech commuters in the western German borderland of Bavaria are compared to other domestic and foreign workers. At the beginning of the 1990s, German legislation was relatively unrestrictive, so that it was quite easy for Czech workers to obtain a work permit beyond the border. Most of them had only low education. More than $5 \%$ of the eastern Bavarian male, low-skilled workforce was reported Czech in the early 1990s. Surprisingly, precisely in this period German employees seem to have benefited from integration, but suffered in the years afterwards, when regulations on labour permits for commuters were far stricter.
\end{abstract}

Keywords: regional labour markets, international migration, cross-border commuting, wage differentials.

JEL Classification: R23, J61, F22

\section{Introduction}

In the process of European integration, regions close to a border are especially affected by labour market liberalisation. In principle, border regions play a special role in an integration process, since effects of transnational competition should be stronger in the absence of the deterrence of costs incurred in order to overcome distance. Only in these regions do "some border crossing activities like commuting, shopping abroad or the cross-border rendering of services (e.g. in construction and crafts) make sense economically due to the short distance to the border" (Mayerhofer, 2004: 74). However, though impediments are decreasing, mental and language barriers still exist, leading to a special economic situation in border regions (van Houtum, 1999), as national borders still matter even in highly integrated areas (McCallum, 1995; Bröcker, 1998; Nitsch, 2000; Gil-Pareja et al., 2006).

When ten Central and Eastern European Countries (CEEC) joined the EU in 2004 and 2007 respectively, most of the Western European countries have imposed

* Michael Moritz, Institute for Employment Research, Regensburger Str. 104, D-90478 Nuremberg, Germany (michael.moritz@iab.de). 
constraints on the transnational free movement of labour. Due to these restrictions most studies on European integration effects of labour movement to EU15 countries deal with countries which lifted the limits directly after the accession of eight new CEEC Member States in 2004, i.e. the UK, Ireland and Sweden. With respect to the labour market in the UK, migration effects - above all from Poland - are analysed in several studies (Gilpin et al., 2006; Blanchflower et al., 2007; Drinkwater et al., 2009). The development in Ireland and Sweden is investigated by Doyle et al. (2006). While there are some contributions using simulations for estimating the effects of future migration, e.g. Brücker (2007), the effects for the regions directly along the former Iron Curtain is quite an open topic in research.

An idiosyncratic situation is arising in this regard directly at the frontier of two countries. The opening of a border leads to a sizable decline in the transaction costs which only then allows the mobility of goods, capital and labour. The theoretical literature on labour mobility overwhelmingly refers either to migration or, as far as commuting is concerned, to urbanised areas (Zax, 1991; van Ommeren et al., 1997; Rouwendal, 1998). Regarding empirical studies, there has also been little research done on EU border effects of transnational commuting, with the exception of some case studies, e.g. Buch et al. (2009) for the Danish-German border region.

Concerning the skill composition of the labour force and returns to education, the demand for more highly skilled workers is increasing throughout the world, not only in industrial countries but also in developing and transition countries (Airola/Juhn, 2005; Skuratowicz, 2005), a stylised fact which is explained by technological change as well as by globalised trade and economic integration. In the 1980s and 1990s this led to an augmented wage inequality most notably in the Anglo-Saxon countries or alternatively to higher unemployment rates of low-skilled workers in continental Europe (Fitzenberger, 1999). Recent studies suggest that wage inequality also increased rapidly in Germany in the 1990s and the early years of the new millennium, above all concerning the low-wage sector (Kohn, 2006; Gernandt/Pfeiffer, 2007; Möller, 2008, among others). Though the overall wage dispersion is smaller in Germany than in the United States, this is mainly due to the high-wage sector in the U.S. (Schettkat, 2007). There is no evidence for the hypothesis that an overly compressed wage structure destroys jobs in Germany. According to Dustmann et al. (2009) technological change leads to higher skill premia for high-skilled employees in western Germany, while the rising wage inequality at the bottom of the distribution is caused by the loss of union power and supply shocks. Concerning former Eastern Bloc countries, until the fall of the communist regimes a real labour "market" did not exist, i.e. unemployment was basically hidden and education-related wage differentials were extremely low. Focusing on the Czech Republic, in the transition years the returns to education increased tremendously, whereas the returns to experience interestingly were rather stable compared to the communist period (Münich et al., 2005).

However, the question of the degree to which the reduction of impediments to economic integration - i.e. the liberalisation of product, capital and labour markets plays a role concerning growing wage differentials has not been satisfactorily resolved. With respect to spatial developments structural changes in labour demand and their effects should emerge outstandingly in the regions which are close to the areas featuring the new opportunities, as long as transportation costs play a decisive role. 
Due to the above mentioned mobility limitations it is in the case of Germany and the Czech Republic important to note that the opening of the border increased the possibilities of trade and international outsourcing, but until now the integration of labour markets has been largely constrained. Germany made use of a limited transition period $(2+3+2$ model) which restricts the free movement of workers from EU accession countries and will probably last until 2011. However, even without transnational labour mobility the integration of product and capital markets affects the labour markets. Furthermore, in the western German border region a special regulation allows Czech commuters to work in Bavaria (the federal state bordering on the Czech Republic) under certain circumstances. The effect of this arrangement, which led to a considerable number of Czech employees coming to the Bavarian border districts in the early to mid 1990s should be of particular interest. Understandably, for Czech workers it was highly appealing to work in Bavaria and earn the multiple higher wages. Basically, real wage differentials between Germany and the Czech Republic are decreasing in the course of economic integration. However, in the mid 1990s wages were at current exchange rates more than eight times higher in the eastern Bavarian border region than in the Czech Republic. Using current Purchasing Power Parities (PPP) the wage differential between Bavaria and Bohemia added up to the ratio of 3.4 (Alecke et al., 2001; Sinn et al., 2001). Therefore, commuters had a particular incentive for cross-border jobs, since they could keep their homes in the Czech Republic and take advantage of the lower cost of living there. Taking the data sets of the German Federal Employment Agency into account, it can be assumed that most of the Czech workers in Bavaria in the early 1990s were commuters. Thus, despite existing restrictions on labour mobility, it is possible to draw conclusions with respect to the impact of Czech commuters on the German labour market by analysing the data for this period. The question arises whether Czech commuters replaced domestic workers or at least pushed their wages down?

In this paper, I highlight the impact of Czech commuters on the labour market in the western German districts close to the Czech Republic in the years after the opening of the border. The unexpected fall of the Iron Curtain in 1989 meets the criteria of a natural experiment. Besides this, one of the world's highest wage differentials exists in this area. Both German employees and Czech commuters in the western German borderland of Bavaria are compared to other domestic and foreign workers. In contrast to Moritz (2009a) the main focus of attention in this paper does not lie on the German workers in the borderlands but above all on the Czech commuters and their impact on the labour market.

The remainder of the paper is structured as follows: Data and basic definitions are described in Section 2. Section 3 contains descriptive evidence on Czech employees in the western German border region. In Section 4 wage differentials using an econometric model are analysed. Section 5 concludes.

\section{Data and Basic Definitions}

I use micro data from the IAB Employment Sample (IABS) for the years 1980 to 2001, which are provided by the Institute for Employment Research (IAB) and contain information about a two percent random sample of all employees covered 
by the German social security system (for a description of the data set see Hamann, 2005). In order to avoid there being too few and insufficient observations for robust estimates for the border region, I include an extract from the employment register (Beschäftigtenhistorik $\mathrm{BeH}$ ) which covers all observations that pertain to social insurance contributions in the eastern Bavarian border region (i.e. 100\% instead of $2 \%$ ). For the analyses I eliminate from the data apprentices, marginal part-time ${ }^{1}$ and part-time workers, homeworkers and all observations where information about education and/or professional status is missing. I concentrate on full-time employees, aged 16 to 65, who will have been employed for at least one year on June 30 (the reference date). Table A1 in the appendix shows mean values of basic variables for German, Czech and other foreign workers. I distinguish between the following three skill groups of workers (Table 1):

Table 1

\section{Classification of Skill Groups}

\begin{tabular}{|l|l|}
\hline Skill group & Qualification \\
\hline low-skilled & $\begin{array}{l}\text { people with no occupational qualification regardless of the educational level } \\
\text { reached, i.e. with or without a certificate of upper secondary education }\end{array}$ \\
\hline skilled & $\begin{array}{l}\text { people with an occupational qualification whether or not they have a certificate of } \\
\text { upper secondary education }\end{array}$ \\
\hline high-skilled & $\begin{array}{l}\text { people with upper secondary education and a degree from a university or } \\
\text { polytechnic }\end{array}$ \\
\hline
\end{tabular}

According to the regulation regarding foreign commuters in German border regions (ASAV 1997, Anwerbestoppausnahmeverordnung - regulation on the granting of employment permits to foreigners), the Bavarian borderland consists of the eastern parts of the regions of Oberfranken (Upper Franconia), Oberpfalz (Upper Palatinate) and Niederbayern (Lower Bavaria) including the university towns of Bayreuth and Passau and the towns with polytechnics (Fachhochschulen) Hof, Weiden, Amberg and Deggendorf (16 districts and seven autonomous municipal authorities, Figure A 1 in the Appendix). In contrast to the border region in ASAV, $\S 6$ para. 1, my analysis covers the city and district of Regensburg. Taking into account the differences between urban and rural areas I use the classification scheme of the Federal Office for Building and Regional Planning (Bundesamt für Bauwesen und Raumordnung BBR), which differentiates between regions with large agglomerations (BBR 1-4), regions with features of conurbation (BBR 5-7) and regions of rural character (BBR 8-9) (Table 2). As a control group I only use the observations from the remaining western German districts (without Berlin), since the inclusion of data from the eastern German states (which are available from 1992 onwards) would lead to biased results.

1 Individuals classed in the category of marginal part time workers are not subject to the statutory unemployment insurance, health insurance and pension schemes. 
Table 2

Regional Classification Scheme Based on BBR Classification

\begin{tabular}{|l|l|l|}
\hline $\begin{array}{l}\text { Structural } \\
\text { region type }\end{array}$ & District type & Description of district type (BBR) \\
\hline \multirow{2}{*}{$\begin{array}{l}\text { Regions } \\
\text { with large } \\
\text { agglomerations } \\
\text { (basic type 1) }\end{array}$} & BBR 1 & Core cities \\
\cline { 2 - 3 } & BBR 2 & $\begin{array}{l}\text { Highly urbanised districts in regions with large } \\
\text { agglomerations }\end{array}$ \\
\cline { 2 - 3 } & BBR 3 & Urbanised districts in regions with large agglomerations \\
\hline $\begin{array}{l}\text { Regions with } \\
\text { features of } \\
\text { conurbation } \\
\text { (basic type 2) }\end{array}$ & BBR 5 & Rural districts in regions with large agglomerations \\
\cline { 2 - 3 } & BBR 6 & $\begin{array}{l}\text { Urbanised districts in regions with intermediate } \\
\text { agglomerations }\end{array}$ \\
\hline $\begin{array}{l}\text { Regions of } \\
\text { rural character } \\
\text { (basic type 3) }\end{array}$ & BBR 7 & Rural districts in regions with intermediate agglomerations \\
\cline { 2 - 3 } & BBR 9 & Urbanised districts in rural regions \\
\hline
\end{tabular}

Source: Federal Office for Building and Regional Planning (Bundesamt für Bauwesen und Raumordnung BBR).

\section{Descriptive Evidence: the Western German Borderland and Czech Employees}

Calculating the share of employees in eastern Bavaria shows the virtually continuous growth of the relative size of the economy in this region (Figure 1a). While around $2.9 \%$ of all workers in western Germany were employed in the eastern Bavarian border region in 1980, this proportion increased to $3.2 \%$ by 2001 . Only in the mid $1990 \mathrm{~s}$ can a temporary decline be observed. Altogether this was not a substantial rise, but the figures show that the opening of the border did not stop the trend. Bearing in mind that German workers could possibly be substituted by Czechs, I only calculate the share for German workers, but, as the graph shows, the development proceeds analogously, i.e. the relative size of the economy in the border region also grew in this respect. Figure $1 \mathrm{~b}$ shows that the employment share of workers employed in the rest of Bavaria also continuously rose until the late $1989 \mathrm{~s}$, then declined for some years and thereafter increased again in the 1990s. Interestingly, the values for the share of German workers are constantly lower than the ratio of all workers in the rest of Bavaria. This indicates that - compared to the western German nationwide level - foreigners are above average employed in the non-eastern Bavarian districts.

In order to evaluate the shifts in the relative wage differentials in eastern Bavaria, it is interesting to take a prima facie view at the skill structure. Figure 2a shows the development of the absolute deviation (as \%) of skill group shares in the eastern Bavarian border region from the national shares averaged over the district types 5-9 in western Germany. From 1980 to 2001 the share of low-skilled workers in eastern Bavaria declines to the nationwide level of district types which are typical for the rather rural structure of this region. In contrast to this development a sharp rise in the share of skilled employees in eastern Bavaria can be observed: the share, which was distinctly below the average in 1980, exceeded the national level moderately in 2001 . 
The deficit of high-skilled workers in eastern Bavaria compared with the average level of the district types 5-9 increased only marginally. Border region effects in terms of a structural break in the distribution of qualification levels resulting from the fall of the Iron Curtain are obviously not observable at the descriptive level. Figure $2 \mathrm{~b}$ gives evidence that, though the levels of deviation are smaller in the rest of Bavaria, the catching-up process in terms of the skill composition was not an exclusively eastern Bavarian phenomenon but took place all over the Free State of Bavaria.

Figure 1

Employment Share of Workers Employed in (a) Eastern Bavaria and (b) the Rest of Bavaria (as \%, 1980-2001)
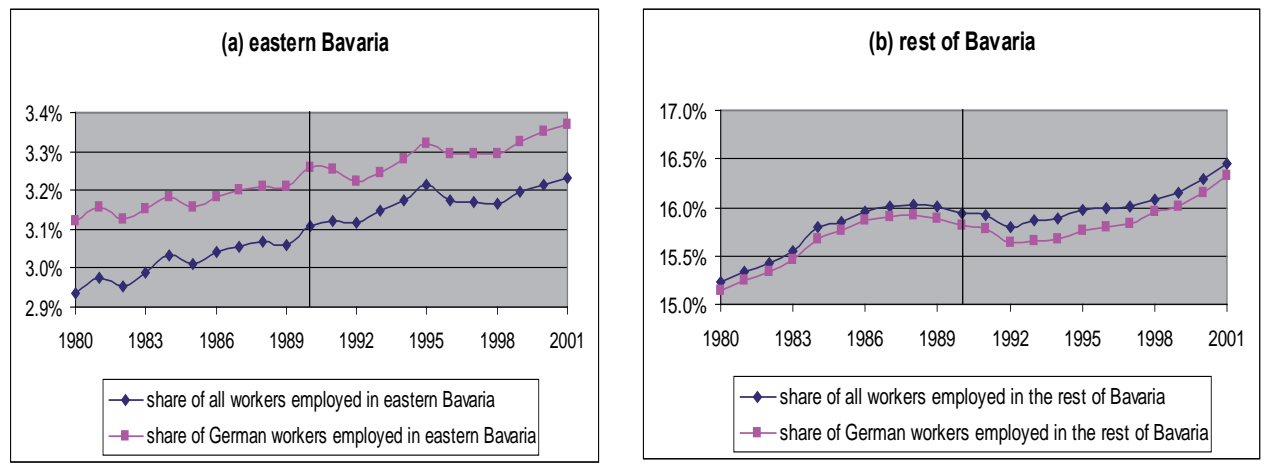

Source: Author's own calculations using the regional scientific use file of the IABS.

Figure 2

Deviation of Skill Group Shares in (a) the Eastern Bavarian Border Region and (b) the Rest of Bavaria from the Averages over the District Types 5-9 in Western Germany (as \%, 1980-2001)
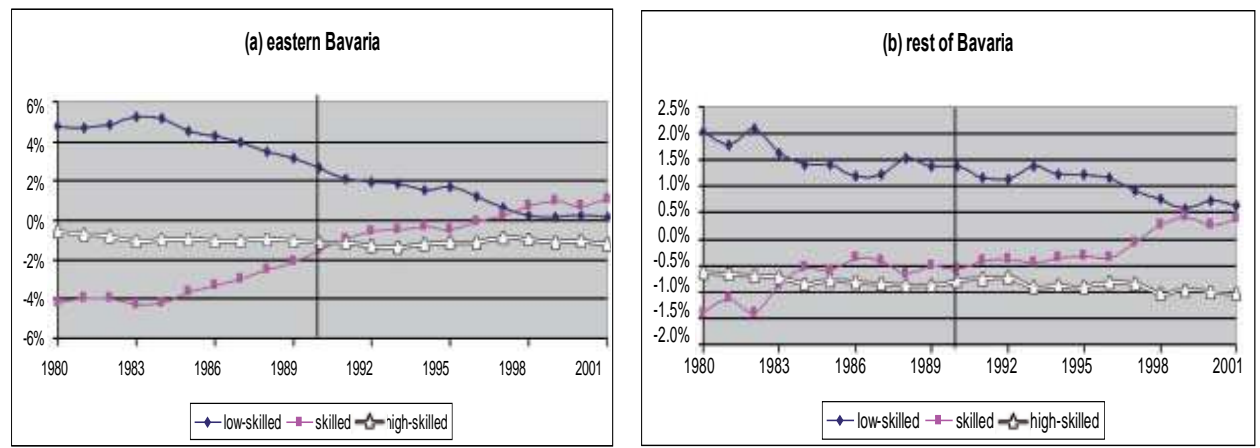

Source: Author's own calculations using the IABS.

According to the abovementioned regulation on the granting of employment permits to foreigners (ASAV, 1997), Czech commuters, i.e. people who cross the border every day or work no more than two days per week in Bavaria, have a facilitated access to the Bavarian labour market compared to other German regions and to conventional migrants. The ASAV came into force in 1997. In the early 1990s it was even easier for Czechs to work in Bavaria. However, due to rising unemployment rates in Germany 
in the mid 1990s, residence and work permits were then only granted or renewed if no German worker could be found for the job. As a consequence the estimated number of Czech commuters working in Germany declined from 16,000 in 1993 to 5,000 in 2000 (Andrle/Dupal, 1997; Prager Zeitung, 2001). The employment figures for Czech workers in Bavaria developed correspondingly - apart from the trend in the hotel and catering industry with an obvious lack of qualified German personnel. Figure 3 depicts the absolute number of Czech commuters in Bavaria, which shows that naturally most of them were employed in the Bavarian border region.

Figure 3

Czech Commuters in Bavaria Covered by the German Social Security System (persons '000, 1992-2001)

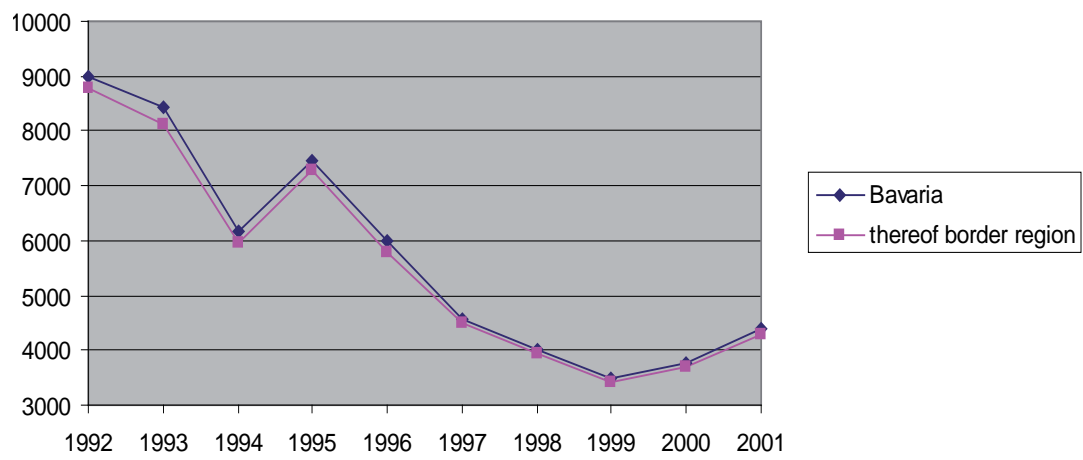

Source: IAB data base.

Notes: reference date: June 30, place of residence/nationality: Czech (Republic), place of work: Bavaria.

Table 3 shows, exemplified for the year 1995, that the Czech commuters were almost exclusively employed in five of the 27 Bavarian employment office districts overall, many of them in the building industry, the hotel and catering industry and the wholesale and retail industry. The share of Czech employees on the total labour force in these five districts ranges from $1.21 \%$ (Hof) to $4.16 \%$ (Weiden). Concerning the qualifications of the commuters, many of them do not have an occupational qualification. This can be discerned by taking a look not only at the commuters, but at all Czech employees in Germany covered by the social security system (Figure A 2 in the Appendix). Using the Employment Register (Beschäftigten-Historik $\mathrm{BeH}$ ) I calculate the share of Czech workers among all workers in the eastern Bavarian border region by including those reported as Czechoslovak (due to the common state until 1992), Czech or Slovak (since a lot of Slovak people still live in the Czech Republic). Plausibly, the share was close to zero before the fall of the Iron Curtain. Only a small number of Czechoslovaks, who are identified as highly skilled, worked in the Bavarian border region. Not surprisingly, the picture changes at the beginning of the 1990s. More than 5\% of the eastern Bavarian male, low-skilled workforce was reported Czech (Czechoslovak, Slovak) in 1992 and 1993. ${ }^{2}$ Corresponding to the development of commuters, the figures decline in the mid 1990s. Regarding female,

2 To simplify matters from now on I use only the term "Czech". 
low-skilled and male, skilled workers the share did not increase to such a large extent, but still reaches $2 \%$. While only a small upswing in the share of female, skilled, Czech workers is observable, the proportion does not increase for high-skilled workers at all.

Table 3

Czech Commuters in the Bavarian Employment Office Districts in 1995

\begin{tabular}{|l|r|l|r|}
\hline employment office district & total & employment office district & total \\
\hline Ansbach & 0 & Deggendorf & 1510 \\
\hline Aschaffenburg & 0 & Donauwoerth & 1 \\
\hline Bamberg & 4 & Freising & 0 \\
\hline Bayreuth & 127 & Ingolstadt & 0 \\
\hline Coburg & 3 & Kempten & 0 \\
\hline Hof & 1078 & Landshut & 6 \\
\hline Nuremberg & 6 & Memmingen & 0 \\
\hline Regensburg & 8 & Munich & 4 \\
\hline Schwandorf & 1806 & Passau & 2063 \\
\hline Schweinfurt & 0 & Pfarrkirchen & 4 \\
\hline Weiden & 829 & Rosenheim & 0 \\
\hline Weissenburg & 0 & Traunstein & 0 \\
\hline Wuerzburg & 1 & Weilheim & 0 \\
\hline Augsburg & 1 & Bavaria & $\mathbf{7 4 5 1}$ \\
\hline
\end{tabular}

Source: IAB data base.

Notes: reference date: June 30, place of residence/nationality: Czech (Republic), place of work: Bavaria.

\section{Econometric Analysis of Wage Differentials}

The aim of this analysis is to estimate whether the opening of the border between Germany and the Czech Republic had a significant effect on the development of wages of German and foreign, especially Czech employees in the eastern Bavarian borderland compared to employees in other western German districts. Focusing on full-time working employees, a Mincerian wage equation (Mincer 1974) is estimated by running crosssectional regressions for each year between 1980 and 2001 separately. The data set is split into yearly subsamples according to the skill and sex groups. Since all observations for the border region from the employment register are used and only a $2 \%$ sample of observations in the non-border region, the observations are weighted adequately to their representativeness. ${ }^{3}$ The regression equation takes the following form:

$$
\begin{gathered}
\text { In } \text { WAGE }_{i}=\alpha+\beta_{1} \text { EXPER }_{i}+\beta_{2} \text { EXPER }_{i}^{2}+\sum_{j=1}^{J=3} \gamma_{j} \text { BBR }_{j i}+\sum_{k=l}^{K=27} \delta_{k} \text { BRANCH }_{k i} \\
+\lambda \text { FOREIGN }_{i}+\tau \text { BORREG }_{i}+\phi \text { BORREG }^{*} \text { FOREIGN }_{i}+\varepsilon_{i}
\end{gathered}
$$

3 Sampling weights are used, i.e. weights that denote the inverse of the probability that the observation is included because of the sampling design. 
The dependent variable $\ln W A G E$ denotes the logarithm of individual $i$ 's daily wage. ${ }^{4}$ For a detailed definition of the exogenous variables see Table 4 . Contrary to the regressions in Moritz/Gröger (2007) not a Tobit model is estimated, but wages are used that, in the case of censoring at the upper ceiling in the German social contribution system, are imputed on the basis of Tobit estimates of the distribution parameters (Gartner, 2005), so that then the standard OLS method can be applied.

Table 4

\section{Variables of the Wage Equation}

\begin{tabular}{|l|l|}
\hline In WAGE & logarithm of individual wage \\
\hline EXPER ( $\mathbf{2 5})$ & potential job experience \\
\hline EXPER $^{2}$ & potential job experience ${ }^{2} / 100$ \\
\hline BBR $^{*}$ & dummies for BBR district types 5,7 and 8 \\
\hline BRANCH $^{*}$ & dummies for industries 1-27 \\
\hline FOREIGN & dummy for foreign workers \\
\hline BORREG & dummy for border region \\
\hline BORREG*FOREIGN & interaction term of BORREG and FOREIGN \\
\hline cons. & Constant \\
\hline
\end{tabular}

In addition to the variables controlling for the potential experience (EXPER, $\left.E X P E R^{2}\right)$ three dummies are used for the basic district types $(B B R)$ and 27 dummies for industries $(B R A N C H)$. Since the workers' potential on-the-job experience (EXPER) cannot be exactly identified, it is measured in years as age minus average duration of education minus six. 10 years as the average duration of education are imposed for low-skilled workers without upper secondary education, 13 years for low-skilled workers with upper secondary education, 12.5 and 15 years respectively for skilled workers, 16 years for high-skilled workers holding a degree from a polytechnic and 18 years for high-skilled university graduates. In order to avoid estimations for a reference group of job entrants only individuals with at least five years of work experience $(E X P E R \geq 5)$ are included. Since the district types 1-4 and 6 do not appear in the border region, observations of these districts are excluded from the estimation. The branches of economic activity are available on the basis of a very detailed 3-digit code (WZ 73) ${ }^{5}$, which is transformed into a scheme of 28 industries. Moreover, a dummy variable for nationality (FOREIGN) is included, which equals one if the employee is not German and zero otherwise. The border region dummy BORREG equals one if the worker is employed in the eastern Bavarian border region and zero if the worker is employed in the rest of western Germany. Thus, the coefficient of BORREG, $\tau$, estimates the wage effect (as \%) for German employees of the respective skill and sex group in the border region compared with the national level. In order to control for foreigners in eastern Bavaria, including the Czech commuters

4 The reason for not using, for instance, hourly wage rates is that the data set covers employees subject to social security containing information on the employment history of employees liable to social security on a daily basis.

5 WZ 73 are the chapters of the classification of commercial sectors, release 1973. 
who legally work in the Bavarian borderland, the nationality dummy is interacted with the border region dummy (BORREG*FOREIGN). The coefficient of this variable measures the wage effect of foreign workers in the border region relative to foreigners in the rest of the country.

The estimation results of the control variables are sensible. ${ }^{6}$ One additional year of potential experience yields a significant wage increase in the first instance, but the benefit declines over time (coefficients of EXPER +,EXPER ${ }^{2}-$ ). The significant coefficient values for most of the dummies for district types and industries provide evidence of both an agglomeration wage premium and inter-industrial wage differentials. The coefficient $\lambda$ controlling for foreign workers exhibits all along the observation period negative values for all male skill groups and for low-skilled female workers. This means, that foreigners belonging to these groups earn less than the relevant domestic German workers. Positive wage differentials for non-Germans are identified for female skilled workers in the 1990s and in some years for female high-skilled workers.

The coefficient $\tau$ of the border region dummy (see Figure A 3 in the Appendix) exhibits, in the case of domestic low-skilled workers, an interesting difference between males (Figure A 3a) and females (Figure A 3b). In the 1980s male low-skilled employees in the eastern Bavarian border region earn about $5 \%$ less than their colleagues in the non-borderlands. This wage differential considerably narrows in the beginning of the 1990 s to around $-3 \%$. Until the end of the decade the wage gap widens again approaching the original level of $-5 \%$. In contrast to this surprising development, there is no similar trend for low-skilled female workers in the border region. Starting from a far smaller wage gap of approximately $-2 \%$ the difference increases in the 1980 s to about $-4 \%$. This level stabilises during the 1990s with only one negative outlier in 1999.

Regarding skilled employees a general catching-up process in eastern Bavaria is clearly evident in the estimates, but interestingly, again only for male employees (Figure A 3c). With earnings of nearly 5.5\% less in 1980, the differential becomes continuously smaller until the mid 1990 s, where it settles at a level of about $3 \%$. Then, similarly to the trend for low-skilled male workers, the graph turns to a deeper wage gap of around $4 \%$ in 1999 with a slight recovery in the following two years. For female skilled workers the picture is completely different again (Figure A 3d). Relative wage losses for employees in the borderlands in the 1980 s (from $-2 \%$ to $-3 \%$ ) are succeeded by a reduction in losses in the 1990 s (from $-3 \%$ to $-2 \%$ ).

As far as high-skilled workers are concerned, the distinctively smaller number of employees holding this skill level poses a problem (apparent in the figures through the huge confidential bounds). Male high-skilled workers in eastern Bavaria (Figure A 3e) earn about $1 \%$ below average until the mid 1980s. In the following ten years the wage differential is positive and then oscillates around the $0 \%$ line. Female high-skilled workers in the border region obviously catch up in the 1980s from below-average to above-average values. In the 1990s the wage level stabilises around the reference value for western Germany (Figure A 3f).

The question arising is which forces are behind the relative wage gains for male low-skilled workers in the early 1990s. One possible explanation could lie in the strengthened position of low-skilled employees in supermarkets and hypermarkets.

Detailed results are available from the author upon request. 
These stores did not exist in the early years after the fall of Communism in the Czech Republic and, like in Poland (Ullmann, 2006), were largely established as recently as the second half of the 1990s. Masses of Czech consumers flocked to the nearby eastern Bavarian stores in these years in order to satisfy their demand for western-type consumer goods. Although the relative employment share in the retail industry grew to a smaller extent by an above-average rate in the border region in the early 1990s (Moritz, 2009b: 59), this did not have a resounding effect on low-skilled workers' wages in eastern Bavaria. Running the regression for low-skilled male workers without those employed in the retail and wholesale industries (and also the other way around only including this subgroup of employees in the regression) does not change the result essentially.

Another reason for the catching-up of low-skilled workers, which is already ruled out here by the specification of the regression model, could be the more productive Czech commuters who potentially substituted less productive German workers at the beginning of the 1990s. Since I control for foreign workers, this cannot cause the positive change in the wage differential. But, as it turns out, it pays off to take a closer look at Czech employees in the Bavarian borderlands.

First of all, I explore the outcomes for the interaction term BORREG*FOREIGN (Figure A 4 in the Appendix). As mentioned above, this variable controls for all foreign workers in eastern Bavaria, measuring their relative wage position compared to all foreign workers in the rest of western Germany. An alternative explanation is the additional wage differential for foreign employees compared to German employees in the border region.

Disregarding high-skilled employees, there are evidently significant changes for the other skill groups after the opening of the border. Slightly positive additional wage differentials for foreign workers in eastern Bavaria in the 1980s turn into negative values of down to $-10 \%$ in the early years after the fall of the Iron Curtain. After these drastic changes, which are mostly apparent for low-skilled and skilled male workers (Figures A 4a and A 4c), the wage differentials stabilise in the mid 1990s, or the trend even reverses, as in the case of low-skilled male workers.

The first suggestion with regard to the reason for these relative wage losses of foreigners in eastern Bavaria is that Czech commuters, for whom it was relatively easy to become employed in the Bavarian borderlands at the beginning of the 1990s, caused the drop in relative wages. Recalling the shares of Czech employees in the different skill groups in eastern Bavaria (Figure A 2), the essential point so far is that the share of Czech workers in the border region is considerably high for precisely those skill groups where I noticed a fall in the relative wages for foreigners after 1990. In order to check definitively whether Czech workers caused the relative wage drop, I estimate the wage differentials excluding Czechs. The revealing results are presented in Figure A 5 (see appendix). The graphs for the skill groups, in which the share of Czech workers did not exceed $1 \%$ in the 1990s (female skilled and both sexes of high-skilled workers), do not change substantially. For the skill groups which exhibit a perceptible increase in the share of Czech employees, however, the graph changes fundamentally if Czechs are excluded from the estimation. For male low-skilled and skilled workers (Figures A 5a and A 5c), as well as for low-skilled female workers (Figure A 5b) - to a smaller degree -, the drop in the relative wage for foreigners estimated above now disappears.

Summarising the regression results, firstly, the estimates shed light on differences between male and female workers. For male low-skilled and skilled workers, who 
represent more than $60 \%$ of the eastern Bavarian workforce, a catching-up process can be verified until the mid 1990s. From 1995 onwards the trend reverses and workers in the border region lose out in relation to employees in the rest of western Germany. Secondly, neither can the substitution of less productive German workers with more productive Czech commuters account for the relative wage gains in the early 1990s, nor can the cause of the growing wage gap in the late 1990s be explained by the available data. Thirdly, Czech workers employed in eastern Bavaria bear the responsibility for the drop in the wage differential for foreign workers in the border region in the early 1990s as their wages were significantly below the wages of other foreigners.

\section{Conclusion}

After all, there is no change for the worse immediately after the opening of the border in the western German districts close to the Czech Republic: indeed, the indications are actually quite positive in the early 1990s. Interestingly, precisely in this period it was relatively easy for Czech commuters to obtain a work permit in Bavaria. The catching-up process above all of male low-skilled employees after the fall of the Iron Curtain is not caused by the substitution of German workers with more productive Czech workers. In fact, Czech employees in eastern Bavaria earned wages substantially below the average in eastern Bavaria. However, from 1995 or so onwards, the development of wages in the border region for domestic workers gives cause for concern.

The results prompt further research on this topic. This paper addresses the consequences of the fall of the Iron Curtain and the following partial labour mobility. Therefore, the findings only indicate the effects of economic integration in a process, which is far from being completed. Since the observation period ends in 2001, the effects of the Czech Republic's accession to the EU in 2004 still have to be analysed, not to mention the impact of free movement of labour, which will bring new opportunities to the Czech workforce in 2011 at the latest, when Germany (and Austria) is obliged to lift the restrictions on the free movement of labour from the Eastern European countries. This should especially affect the economies of the districts which have a common border with the eastern neighbour countries. Though the implementation of free cross-border labour mobility is a large step in an ongoing integration process, its effects should act in the same direction as those that came into force after the opening of the border in 1989 and the abolition of trade impediments and tariffs afterwards.

In contrast to the sometimes negative assessment of the popular Western European press, it is not so obvious which countries and regions respectively will profit and which will suffer from labour mobility. Basically, the Czech Republic, now surrounded only by EU Member States, holds a favourable position. However, the shortage of skilled labour ("brain drain"), for instance, is becoming an increasing problem in the Czech Republic which could worsen by the easier access on the Western European labour markets. On the other hand, it is hardly predictable to what extent the incentive of higher incomes in a neighbouring country will influence the Czechs, who have so far been rather immobile.

The findings of this paper indicate that there are no profound negative labour market effects of Czech commuters on the eastern Bavarian workforce. This outcome should encourage politicians, business people and employees to look quite calmly forward to the implementation of free movement of labour between Germany and the Czech 
Republic in 2011. As German low-skilled workers were not hurt by commuters even in the districts close to the border, the overall effect for the whole of Germany should be very small. Moreover, the convergence of real wage levels and purchasing power of the two countries (Eurostat 2008, 2009) will prevent a mass immigration of Czech workers in Germany. Free cross-border commuting can even have positive impacts on the availability of employees where the workforce is scarce in Germany, e.g. in the field of household-related services or nursing staff. The $2+3+2$ model restricting full labour mobility evidently prolongated an adjustment process which in the long run will lead to similar living conditions on both sides of the border. The monitoring of economic integration in the observed area has to be tackled in further studies. In general, the interactions between the Western and Eastern European labour markets leave scope for continuous research.

\section{References}

Airola, J., Juhn, C. (2005), "Wage Inequality in Post-Reform Mexico." Bonn: IZA Discussion Paper No. 1525.

Alecke, B., Hofmann, H., Meier, V., Riedel, J., Scharr, F., Untiedt, G., Werding, M. (2001), "Auswirkungen der EU-Osterweiterung auf Wirtschaft und Arbeitsmarkt in Bayern." Study for the Bavarian State Ministry of the Economy, Transport and Technology. Munich: ifo.

Andrle, A., Dupal, J. (1997), "Arbeitsmarkt und regionale Disparitäten in der Tschechischen Republik," in Fassmann, H., ed., Die Rückkehr der Regionen. Beiträge zur regionalen Transformation Ostmitteleuropas, Beiträge zur Stadt- und Regionalforschung Band 15. Vienna: Verlag der Österreichischen Akademie der Wissenschaften, pp. 37-82.

ASAV - Anwerbestoppausnahmeverordnung (1997), http://bundesrecht.juris.de/asav/ (accessed January 22, 2010).

Blanchflower, D., Saleheen, J., Shadforth, C. (2007), "The Impact of the Recent Migration from Eastern Europe on the UK Economy." Bonn: IZA Discussion Paper No. 2615.

Bröcker, J. (1998), "How Would an EU-Membership of the Visegrád Countries Affect Europe's Economic Geography?" Annals of Regional Science, 32 (1), pp. 91-114.

Brücker, H. (2007), "Labor Mobility after the European Union's Eastern Enlargement: Who Wins, Who Loses?" Washington: GMF Paper Series.

Buch, T., Dall Schmidt, T., Niebuhr, A. (2009), "Cross-Border Commuting in the Danish-German Border Region - Integration, Institutions and Cross-Border Interaction." Journal of Borderlands Studies, 24 (2), pp. 38-54.

Doyle, N., Hughes, G., Wadensjö, E. (2006), "Freedom of Movement for Workers from Central and Eastern Europe. Experiences in Ireland and Sweden." Stockholm: Swedish Institute for European Policy Studies, Report No. 5/2006.

Drinkwater, S., Eade, J., Garapich, M. (2009), "Poles Apart? EU Enlargement and the Labour Market Outcomes of Immigrants in the United Kingdom." International Migration, 47 (1), pp. 161-90.

Dustmann, C., Ludsteck, J., Schönberg, U. (2007), "Revisiting the German Wage Structure." The Quarterly Journal of Economics, 124 (2), pp. 843-81.

Eurostat (2008), Regional Yearbook. Luxembourg: European Union.

Eurostat (2009), Regional Yearbook. Luxembourg: European Union.

Fitzenberger, B. (1999), "International Trade and the Skill Structure of Wages and Employment in West Germany." Jahrbücher für Nationalökonomie und Statistik, 219 (1-2), pp. 67-89.

Gartner, H. (2005), "The Imputation of Wages above the Contribution Limit with the German IAB Employment Sample." Nuremberg: Institute for Employment Research, FDZ Methodenreport 2/2005. 
Gernandt, J., Pfeiffer, F. (2007), "Rising Wage Inequality in Germany.“ Jahrbücher für Nationalökonomie und Statistik, 227 (4), pp. 358-80.

Gil-Pareja, S., Llorca-Vivero, R., Martínez-Serrano, J. A. (2006), "The Border Effect in Spain: The Basque Country Case." Regional Studies, 40 (4), pp. 335-45.

Gilpin, N., Henty, M., Lemos, S., Portes, J., Bullen, C. (2006), "The Impact of Free Movement of Workers from Central and Eastern Europe on the UK Labour Market." London: Department for Work and Pensions, Working Paper No. 29.

Hamann, S. (2005), "Die regionale IAB-Beschäftigtenstichprobe IABS-R01," in Grözinger, G., Matiaske, W., eds., Deutschland regional - sozialwissenschaftliche Daten im Forschungsverbund. München und Mering: Rainer Hampp Verlag, pp. 81-87.

Kohn, K. (2006), "Rising Wage Dispersion, After All! The German Wage Structure at the Turn of the Century." Mannheim: ZEW Discussion Paper 06-31.

Mayerhofer, P. (2004), "Austrian Border Regions and Eastern Integration." Review of Regional Research, 24 (1), pp. 73-104.

McCallum, J. (1995), "National Borders Matter: Canada-US Regional Trade Patterns." American Economic Review, 85 (3), pp. 615-23.

Mincer, J. (1974), Schooling, Experience, and Earnings. New York: Columbia University Press.

Möller, J. (2008), "Wage Dispersion in Germany Compared to the US - Is there Evidence for Compression From Below?" International Economics and Economic Policy, 5 (4), pp. 345-61.

Moritz, M. (2009a), "The Impact of European Integration on Wage Differentials in the Bavarian-Czech Border Region." Wirtschafts- und Sozialstatistisches Archiv AStA, 3 (2), pp. 137-51.

Moritz, M. (2009b), Labour Market Effects of European Integration in the Bavarian and Czech Border Regions. IAB-Bibliothek, 321, Dissertation, Bielefeld: Bertelsmann.

Moritz, M., Gröger, M. (2007), "Labor Market Effects in the German-Czech Border Region - an Empirical Study Using the IAB Employment Sample (IABS).“ Journal of Borderlands Studies, 22 (2), pp. 57-76.

Münich, D., Svejnar, J., Terrell K. (2005), "Returns to Human Capital Under the Communist Wage Grid and during the Transition to a Market Economy." Review of Economics and Statistics, 87 (1), pp. 100-23.

Nitsch, V. (2000), "National Borders and International Trade: Evidence from the European Union." Canadian Journal of Economics, 33 (4), pp. 1091-1105.

Prager Zeitung (2001), "Zur Arbeit über die Grenze." February 15.

Rouwendal, J. (1998), "Search Theory, Spatial Labor Markets, and Commuting." Journal of Urban Economics, 43 (1), pp. 1-22.

Schettkat, R. (2007), "Sind 3 Euro schon zu viel? Aufklärendes zu Lohnspreizung und Beschäftigung." WSI Mitteilungen, 6/2007, pp. 335-43.

Sinn, H.-W., Flaig, G., Werding, M., Munz, S., Düll, N., Hofmann, H. (2001), “EU-Erweiterung und Arbeitskräftemigration - Wege zu einer schrittweisen Annäherung der Arbeitsmärkte." Munich: Ifo-Beiträge zur Wirtschaftsforschung Nr. 2.

Skuratowicz, A. (2005), "Growing Wage Inequalities in Poland: Could Foreign Investment Be Part of the Explanation?" Brussels: European Commission, ECFIN Country Focus, 2 (5), pp. 1-5.

Ullmann, H. (2006), "Die Situation des Einzelhandels in Polen." Osteuropa-Wirtschaft, 51 (1) pp. 17-29.

van Houtum, H. (1999), "What is the Influence of Borders on Economic Internationalisation?" in de Gijsel, P., Janssen, M., Wenzel, H.-J., Woltering, M., eds., Understanding European CrossBorder Labour Markets. Marburg: Metropolis-Verlag, pp. 107-41.

van Ommeren, J., Rietveld, P., Nijkamp, P. (1997), "Commuting: In Search of Jobs and Residences." Journal of Urban Economics, 42 (3), pp. 402-21.

Zax, J. (1991), "Compensation for Commutes in Labor and Housing Markets." Journal of Urban Economics, 30 (2), pp. 192-207. 


\section{Appendix}

Figure A 1

Eastern Bavarian Border Region

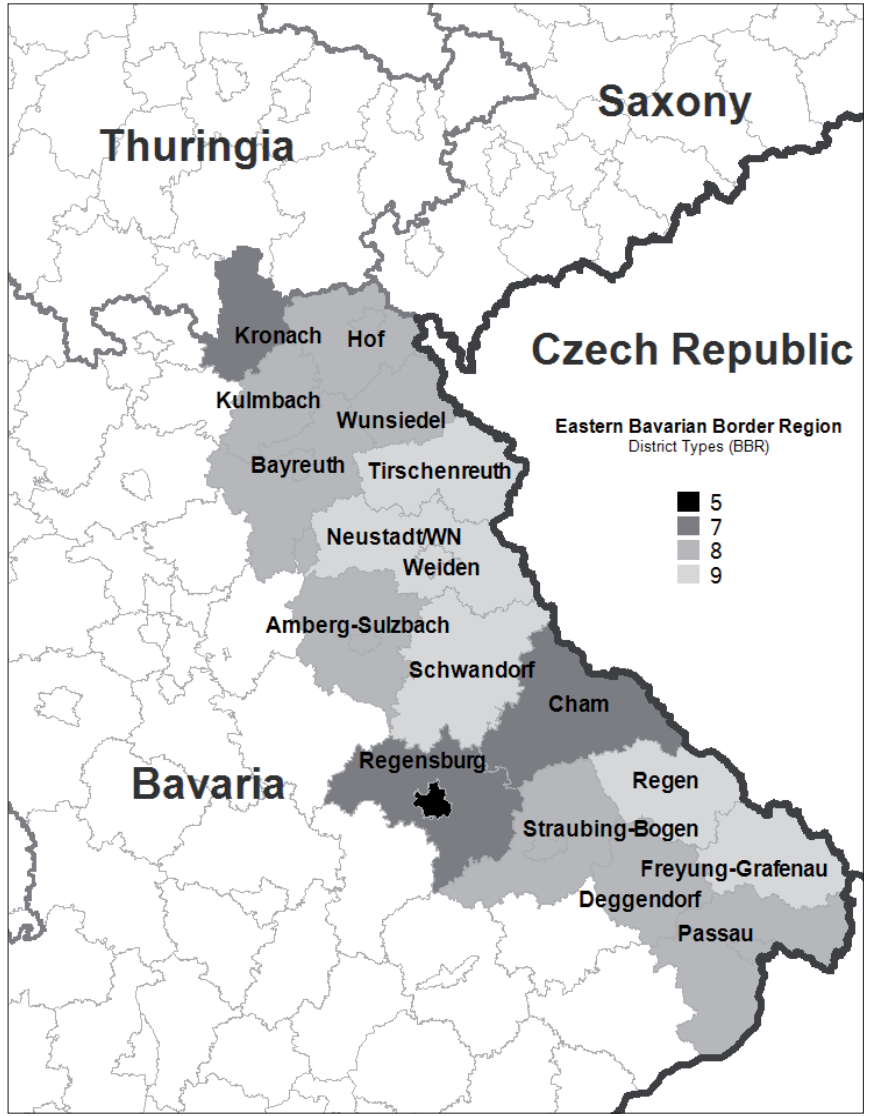

Table A1

Means of Basic Variables for German, Czech and Other Foreign Workers

\begin{tabular}{|l|r|r|r|}
\hline variable & German & Czech & other \\
\hline Gender: female & 0.35 & 0.20 & 0.31 \\
\hline Age & 36.50 & 35.77 & 36.26 \\
\hline Potential Experience & 18.39 & 18.15 & 18.97 \\
\hline Primary sector & 0.02 & 0.02 & 0.01 \\
\hline Secondary sector & 0.57 & 0.71 & 0.72 \\
\hline Tertiary sector & 0.41 & 0.27 & 0.28 \\
\hline
\end{tabular}

Source: Author's own calculations with employment register (Beschäftigten-Historik BeH). 
Figure A 2

Share of Czech Employees in the Eastern Bavarian Workforce (as \%, 1980-2001)
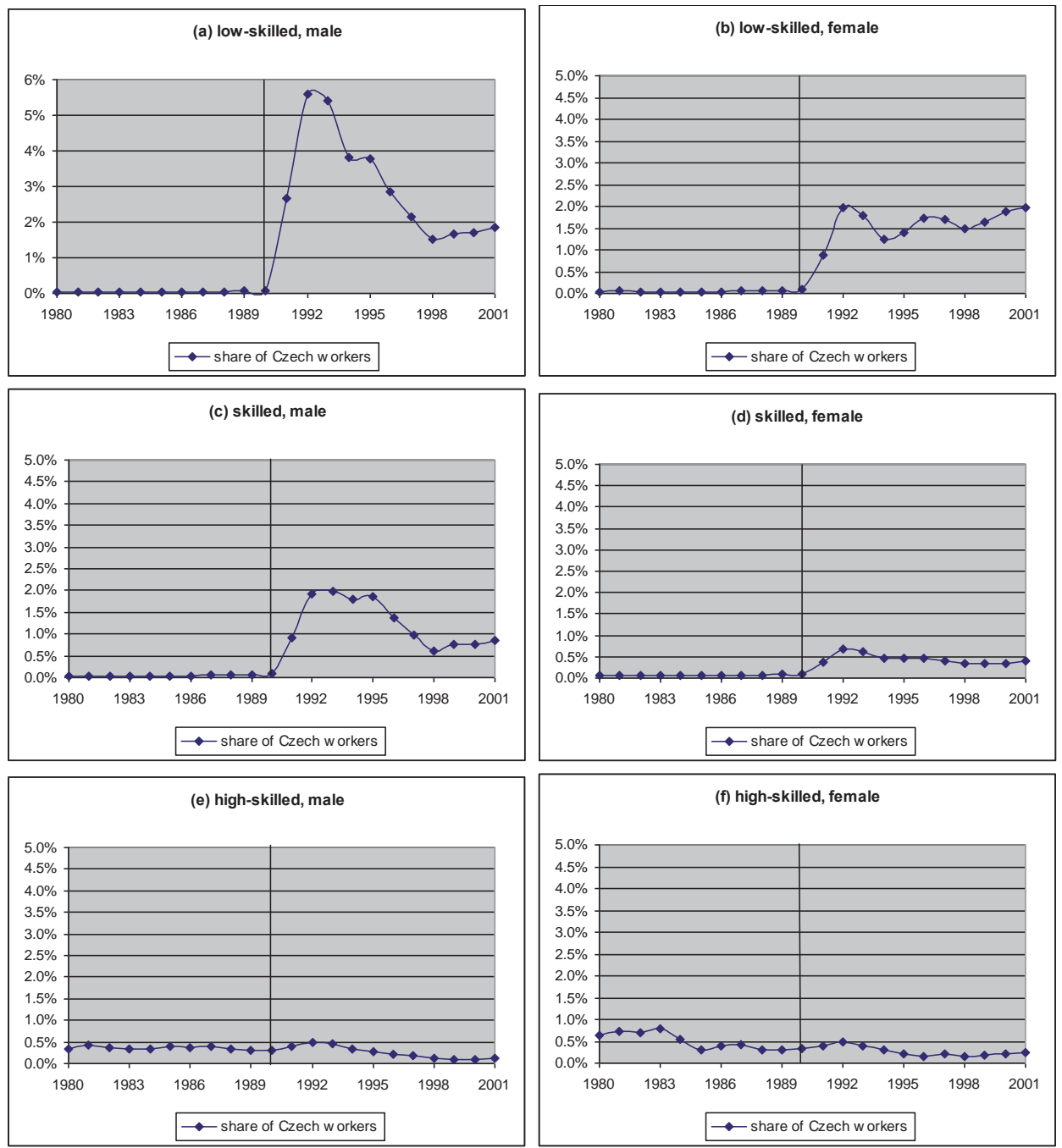

Source: Author's own calculations with employment register (Beschäftigten-Historik BeH). 
Figure A 3

Gender-Specific Wage Effect for German Employees in Eastern Bavaria (as \%, 1980-2001)
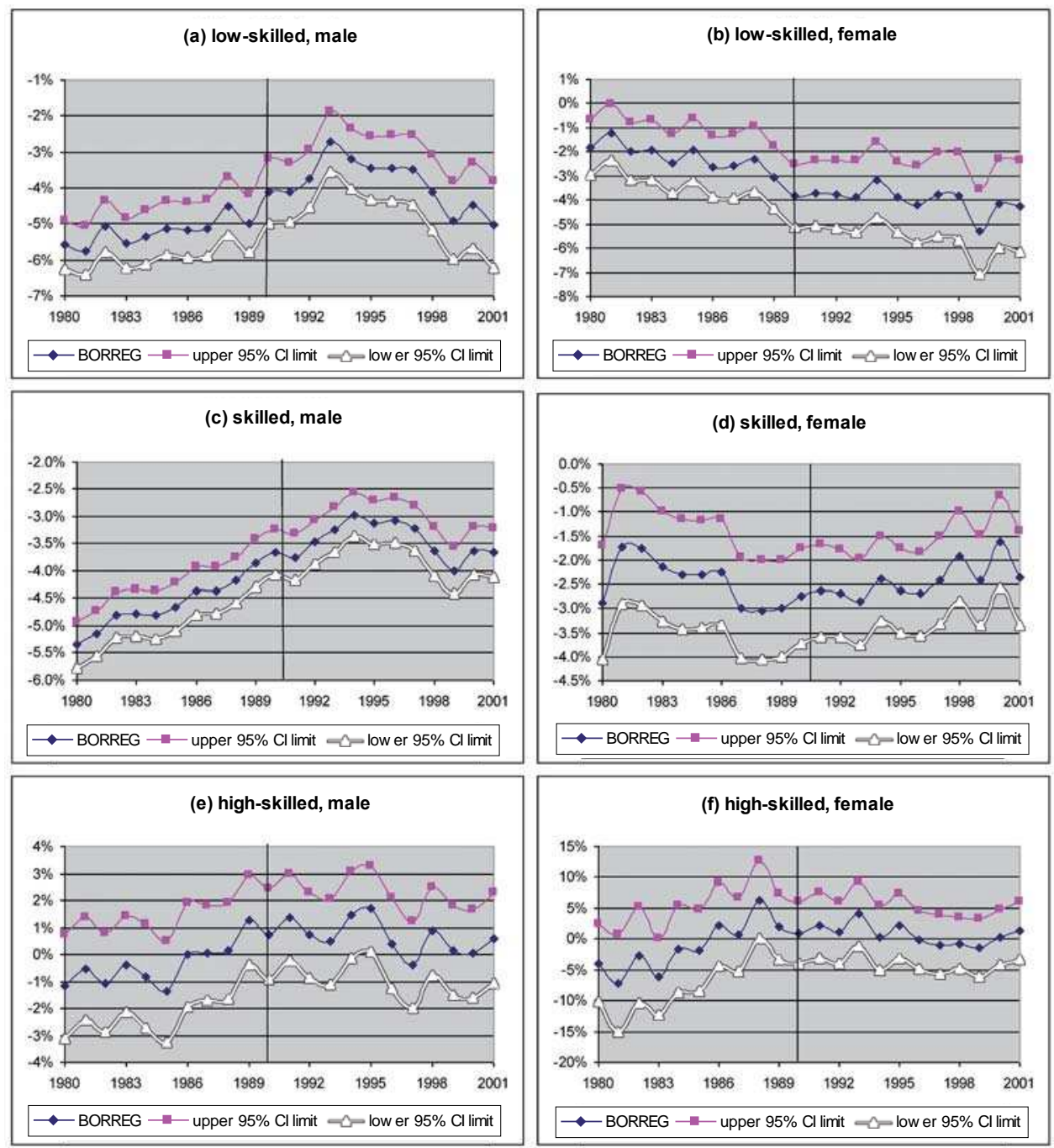

Source: Author's own calculations using the weakly anonymous version of the IABS and BeH extract. Notes: In the case of censoring, wages are calculated in the framework of an imputation procedure using the Tobit estimation method; regression with heteroskedasticity-robust standard errors. 
Figure A 4

Additional Wage Effect for Foreign Employees in Eastern Bavaria (as \%, 1980-2001)
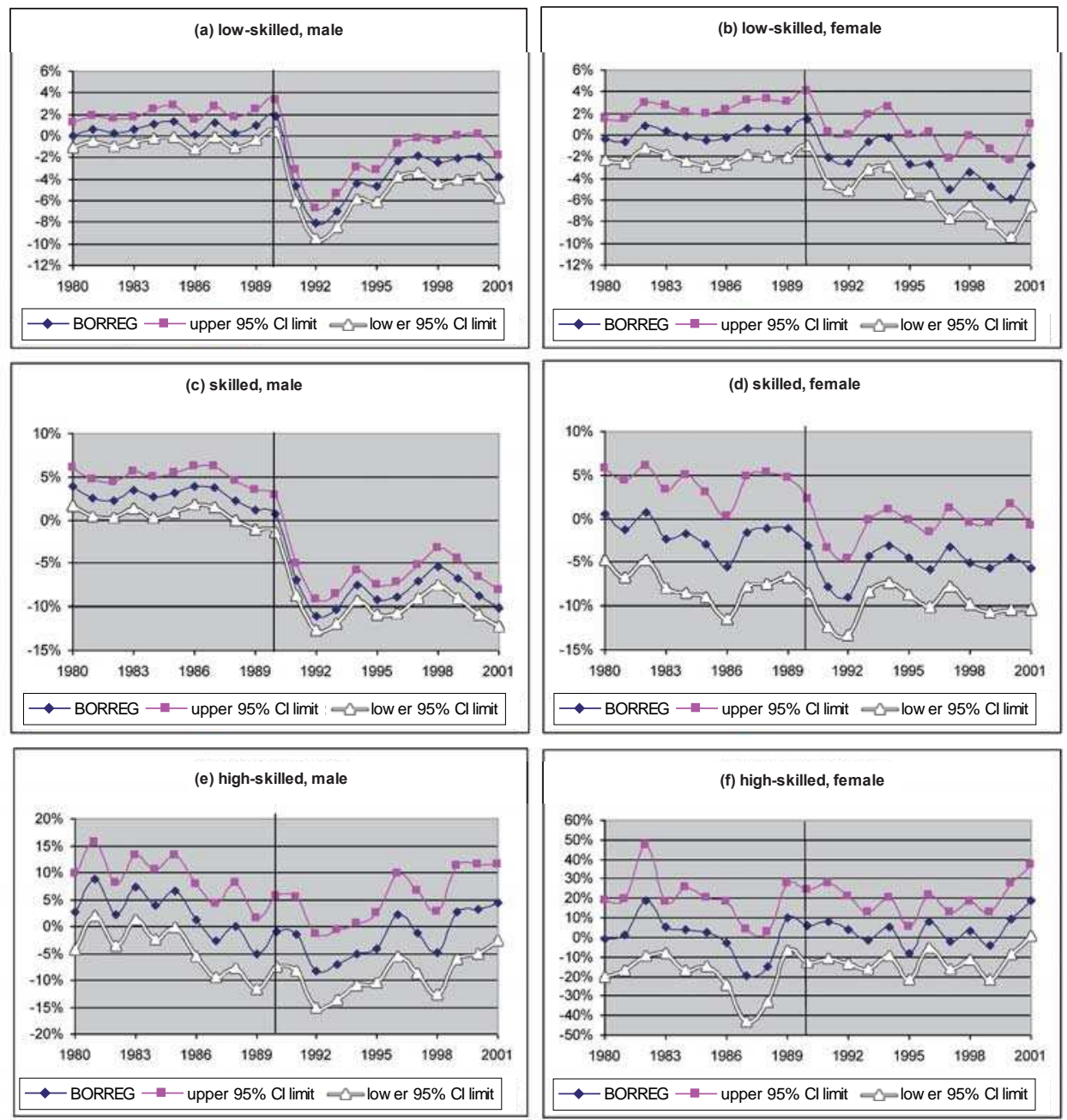

Source: Author's own calculations using the weakly anonymous version of the IABS and BeH extract. Notes: In the case of censoring, wages are calculated in the framework of an imputation procedure using the Tobit estimation method; regression with heteroskedasticity-robust standard errors. 

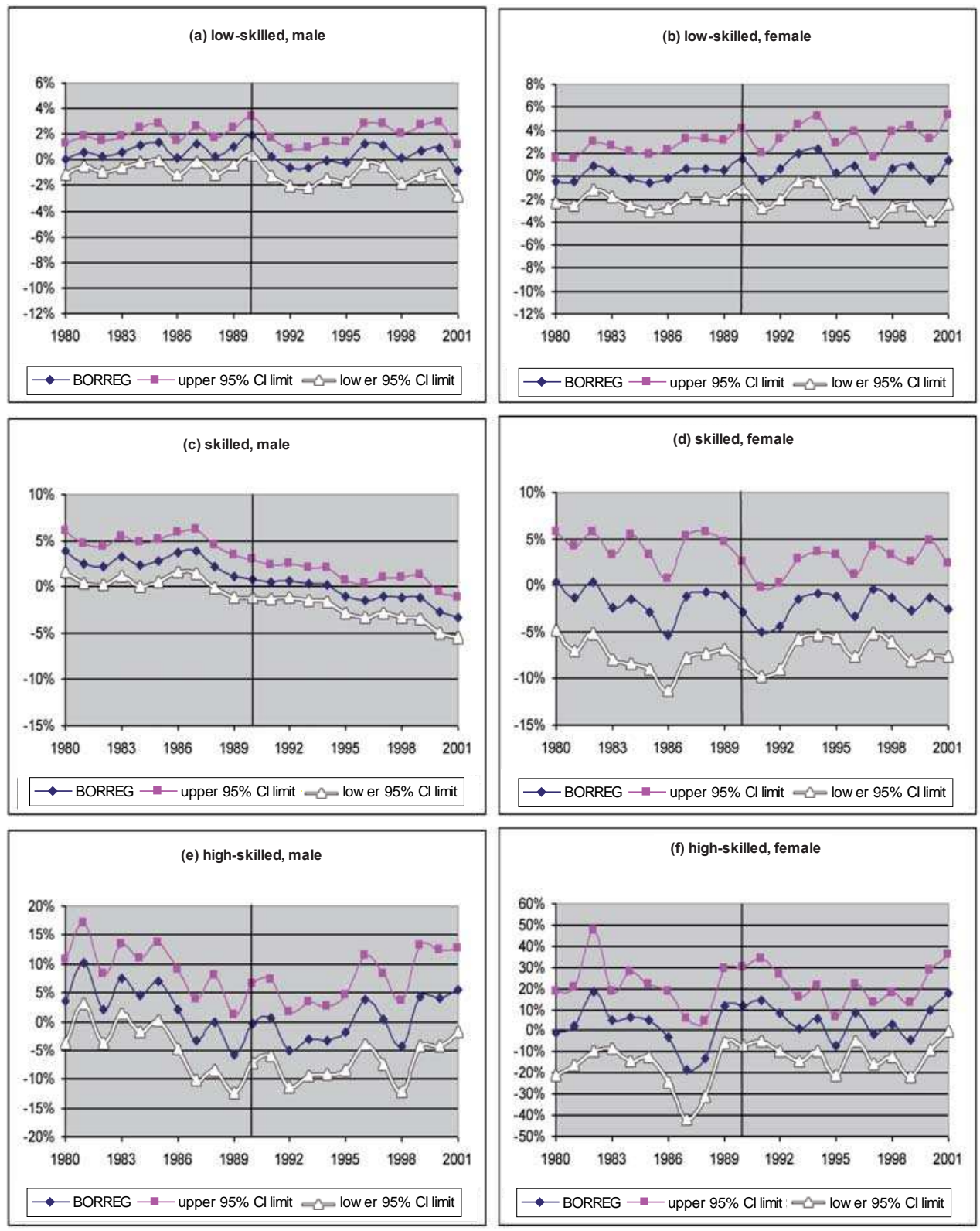

Source: Author's own calculations using the weakly anonymous version of the IABS and BeH extract.

Notes: In the case of censoring, wages are calculated in the framework of an imputation procedure using the Tobit estimation method; regression with heteroskedasticity-robust standard errors. 